\title{
Fish Health Management Considerations in Recirculating Aquaculture Systems - Part 1: Introduction and General Principles ${ }^{1}$
}

Roy P.E. Yanong ${ }^{2}$

\section{Introduction}

Recirculating aquaculture systems, also known as water reuse systems, are commonly found in aquaculture production facilities, public aquaria, tropical fish wholesale operations, and retail pet stores. When properly managed, these systems have the advantages of both reducing overall water usage, as compared to flow-through systems, and improving control of many aspects of nutrition and water quality, as compared to pond systems.

However, recirculating systems have their own unique set of problems. They are not a substitute for good management and often require more time and care than flow-through systems. They certainly are not a "silver-bullet" for eliminating fish diseases.

In addition, defining the primary intended use of a system will help optimize efficiency and utility in the design process.

This series of circulars - Fish Health Management Considerations in Recirculating Aquaculture Systems: Parts 1, 2 and 3 - provides basic information that should assist the beginning- or intermediate-level aquaculturist interested in working successfully with recirculating systems. This circular, Part 1, provides basic principles and guidelines for preventative medicine and system design. Part 2 explains the role of pathogens in recirculating systems, and Part 3 provides some general recommendations and approaches to solving common problems with water quality and fish health. This series is a starting point for anyone considering installing or currently using a recirculating system.

Any manager of fish health seeks to achieve two goals:

- to maximize immunocompetence in fish populations; and

- to reduce or eliminate potential pathogens (i.e., parasites, bacteria, viruses and fungi) in culture systems.

These two goals are best achieved through understanding and following the principles of preventative medicine.

1. This document is Circular 120, one of a series of the Fisheries and Aquatic Sciences Department, Florida Cooperative Extension Service, Institute of Food and Agricultural Sciences, University of Florida. Original publication date: December 2003. Visit the EDIS Web Site at http://edis.ifas.ufl.edu.

2. Roy P.E. Yanong, Assistant Professor, Tropical Aquaculture Laboratory, Ruskin FL 33570, Department of Fisheries and Aquatic Sciences, Florida Cooperative Extension Service, Institute of Food and Agricultural Sciences, University of Florida, Gainesville, FL 32611.

The Institute of Food and Agricultural Sciences is an equal opportunity/affirmative action employer authorized to provide research, educational information and other services only to individuals and institutions that function without regard to race, color, sex, age, handicap, or national origin. For information on obtaining other extension publications, contact your county Cooperative Extension Service office. Florida Cooperative Extension Service/Institute of Food and Agricultural Sciences/University of Florida/Christine Taylor Waddill, Dean. 


\section{Different Systems for Different Purposes}

A recirculating system should be designed with a specific purpose in mind and in a way that makes it easy to follow the principles of preventative medicine. The retrofitting of systems that were poorly designed is usually costly and time-consuming. Recirculating systems should be built so that each tank or vat can be taken off line and run independently from all other tanks or vats in the system. This way, each tank or vat can be operated in isolation from the whole system for quarantine or treatments if necessary. During planning, consult a specialist on recirculating systems or aquaculture systems for advice.

In general, there are five main purposes for recirculating systems.

Grow-out systems These require rigorous management of water quality and nutrition, due to higher concentrations of fish, higher levels of feeding, and expectations for rapid growth. Usually, the number of different species per system is limited.

Breeding systems These systems often require more complex designs than grow-out systems, especially grow-out systems for older juveniles. Water quality parameters, including temperature, photoperiod (the intervals of light and darkness during 24 hours), $\mathrm{pH}$, hardness, and conductivity, often have to be manipulated to trigger spawning. In addition, effective breeding size, behavior, and social structure of the fish must all be considered when choosing the type and size of tanks or vats (some fish require larger territories to breed efficiently, others may require only a very small volume) and type and location of drains.

\section{Long-term holding systems (including} quarantine systems) These systems are usually designed to house older juvenile, subadult, or adult fish for several weeks, months or longer. Feeding loads are not as high as in grow-out facilities because the fish in these systems are typically older and no longer in rapid growth phase. However, they are being held for a longer period of time compared to fish in short-term holding systems and they still require a regular, complete diet, which makes feeding load a concern.

Short-term holding systems These are found in pet fish retail stores and wholesale operations, and typically house fish for 1-21 days. These systems must accommodate frequent introductions and rapid fluctuations in both numbers of fish and varieties of species. Thus, they require greater flexibility in their design and biofilter capacity. Nutritional requirements are not as stringent because of the relatively short holding time.

Display systems These systems, most often found in public aquaria, also require rigorous management with suspended particulates, dissolved organics, and water clarity becoming more important factors. In addition, numerous species are often kept together and many display systems remain essentially unchanged for years. In these systems, chronic diseases resulting from long-term, but subtle nutritional imbalances, or from specific disease-causing organisms, such as Mycobacterium spp., are of more concern.

\section{Preventative Medicine Principles}

Preventing disease by observing the essential principles of fish health management is the most cost effective management scheme for recirculating systems and all other aquaculture systems (see UF/IFAS Circulars 919 Stress - Its Role in Fish Disease and 921 Introduction to Fish Health Management). The principles include understanding and attending to: 1) species biology, including all known and important genetic considerations; 2) nutrition; 3) water quality; 4) quarantine; 5) sanitation; and 6) disinfection. Understanding species biology, nutrition, and water quality will help managers optimize immune systems. Quarantine, sanitation and disinfection reduce or eliminate potential pathogens (disease-causing organisms), and are important components of a good biosecurity program (see biosecurity section below). Use of appropriate management techniques maximizes the effectiveness of recirculating systems and minimizes disease outbreaks. 
Species biology A basic knowledge of the anatomy, physiology, behavior, genetics, social interactions and environmental needs of cultured species is critical to proper management. Some fish, such as cichlids, may be very aggressive toward each other, and they may even eat smaller members of their species. Some species may require a culture system with a large surface area rather than a large volume (e.g., four-eyed fish, Anableps). Other species may require specific substrates or habitats. For example, shell-dwelling cichlids fare best with shells or pipes in the tank.

The genetics of many species are not well known, and their effects may be subtle. However, some dramatic diseases have a known genetic cause and in these cases, genetic selection is important when choosing potential broodstock. Some of these diseases include: "saddleback" (abnormal dorsal fin or death) in tilapia, a condition controlled by a single gene; poor survivability among black angelfish offspring; early death of offspring from crosses of koi with certain scale patterns (the result of two different genes interacting); and the potential for inbreeding depression. Inbreeding depression refers to a reduction in things such as survivability, desirable traits (such as size and color), or overall health resulting from many generations of brother to sister or parent to offspring crosses. Inbreeding depression results from increases in the number of unwanted or harmful genes present and "turned on" in a population.

Similarly, proper broodstock selection is important to avoid breeding out of a population genes that result in desirable properties (e.g., larger size, long fins, color, scale type).

Nutrition Nutritional considerations include size, palatability ("attractiveness by taste") and quantity of pellets, granules or live foods; frequency of feeding, lighting (some species may prefer to eat during the day, at night, or at "dusk"), optimal temperature (species have a preferred temperature for feeding, or may have reduced requirements when temperatures are lower); as well as the bioavailability, quality and quantity of micronutrients (vitamins, minerals) and macronutrients (protein, fat, carbohydrate) in the diet. Fish raised in outdoor ponds frequently benefit from live foods present, but these nutritional sources are not available in most recirculating systems (exceptions include green water systems and pond recirculating systems).

Consequently, nutritionally-complete diets are essential for fish reared in intensive recirculating systems.

Unfortunately, the details of what constitutes a nutritionally-complete diet are not known for all species. Gross deformities in several species of fish have been reported from production facilities using recirculating systems. In particular, the cyprinids ("carp-like" fish, including barbs, freshwater sharks, and koi) may grow slowly and become particularly susceptible to musculoskeletal and opercular abnormalities. Cyprinids lack a true acid-producing stomach, so they cannot digest certain forms of phosphorus, including tribasic calcium phosphate and hydroxyapatite, derived from bone and scales, which may contribute to abnormalities in these fish due to the fishs inability to break down and use phosphorus from these compounds. More soluble forms of phosphorus, such as monobasic phosphates of potassium, sodium, or calcium, are recommended (National Research Council 1993).

Water quality First and foremost, water quality must be compatible with the requirements of the fish being held, especially with regard to ammonia, nitrite, nitrate (in marine systems), $\mathrm{pH}$, temperature, dissolved oxygen, hardness, alkalinity, and salinity. Although initial water quality in a system will be determined by water source and water treatment regimes, the long-term water quality in a recirculating system depends on numerous factors. The most important considerations are the source of water in the system, fish load, feeding rates, and biofilter capacity.

Water from the source should be evaluated by an aquaculture specialist and a water-testing laboratory before a system is established. Water from different sources may have different potential problems that must be addressed. Municipal water may contain chlorines or chloramines; well water may contain hydrogen sulfide, supersaturated gases (such as nitrogen gas, resulting in gas bubble disease), high carbon dioxide levels, and low oxygen levels, or high 
dissolved iron levels, (all conditions that can be lethal to fish if not corrected); surface water sources may be high in bacteria or toxic chemicals resulting from run off.

The most common water quality problems in recirculating systems are toxic levels of ammonia or nitrite caused by imbalances between the capacity of the biofilter and the fish load and feeding rates. This problem often occurs during the start up of a system, although it may occur at any time. The bacteria in the biofilter can require three to eight weeks to cycle (i.e., become established) at $25-27^{\circ} \mathrm{C}\left(77-81^{\circ} \mathrm{F}\right)$ and even more time may be required at cooler temperatures (see UF/IFAS Fact Sheet FA-16 Ammonia). Aquaculturists will often begin this cycling process prior to the addition of fish by one of the following methods:

- adding ammonia directly into the system;

- adding a species of fish (such as black tetras, Gymnocorymbus ternetzi) that is more tolerant of the initial high ammonia and nitrite levels before adding the final species to be held; or

- seeding the system/biofilter with bacteria from a "healthy" established system or with bacteria from a reputable commercial source.

In established filters, toxic levels of ammonia and nitrite may result from overfeeding, crowding, or inefficient removal of solids (such as feces and uneaten food), resulting in breakdown of large quantities of proteins into ammonia.

However, in addition to problems caused by source water issues, ammonia, and nitrite (described above), problems can also result from changes in water quality parameters that were previously acceptable. Parameters that can change over time in a system include dissolved oxygen (DO, decreases), alkalinity (decreases), carbon dioxide (can increase), and $\mathrm{pH}$ (decreases).

Low DO can occur during operation of a system as the result of many different causes. Some of these include: high stocking densities, inadequate water flow, inadequate aeration, high organic loads in the system that lead to large numbers of bacteria in addition to those in the biofilter, high feeding rates or the use of certain chemicals such as formalin (see UF/IFAS Fact Sheet VM-77 Use of Formalin to Control Fish Parasites).

Recirculating systems with little loss or addition of water often undergo gradual $\mathrm{pH}$ drops, a result of gradual acid addition and alkalinity reduction in the system. The bacteria in the biofilter produce acid $\left(\mathrm{H}^{+}\right)$as a by-product of nitrification (the process occurring in the biofilter that converts toxic ammonia and nitrite into much less toxic nitrate). In other words, as ammonia is converted to nitrite and nitrite is converted to nitrate, Hydrogen ions $\left(\mathrm{H}^{+}\right)$are released into the water. This acid then uses up the carbonates and bicarbonates by combining with them (which essentially neutralize them), causing a reduction in alkalinity. Drops in alkalinity may result in ammonia and nitrite spikes because, in addition to oxygen, ammonia, and nitrite, the biofilter bacteria require the bicarbonate portion of alkalinity for survival and growth.

Acids also come from the decomposition of uneaten food and fish wastes and from carbon dioxide released by the fish and bacteria in the water. All of these acid additions react with the bicarbonates and carbonates, removing them from the water and also leading to drops in alkalinity.

In addition to alkalinity's importance for biofiltration, alkalinity is very important as a $\mathrm{pH}$ buffer. Components of alkalinity (especially carbonates and bicarbonates), as described above, neutralize acids, and help to prevent major drops in $\mathrm{pH}$ that would otherwise occur. However, if the alkalinity does reach a critically low level, the $\mathrm{pH}$ of the water will drop rapidly and have detrimental effects on the fish and biofilter.

Minimum alkalinity levels recommended for good biofiltration range from 100-180 ppm (in particular, the levels of bicarbonate and carbonate ions).

Holding species that thrive in lower $\mathrm{pH}$ and lower alkalinity, such as discus, can make maintenance of a balanced biofilter much more challenging. 
Some management options to prevent this drop in alkalinity and $\mathrm{pH}$ and the potential rise in ammonia and nitrite include:

- routine (once a week to once a month, depending upon stocking density) measurement of alkalinity and $\mathrm{pH}$, in addition to other parameters mentioned previously;

- partial water changes on a routine basis (amount dependent upon drops in alkalinity and $\mathrm{pH}$ over time) as long as the source water has an adequate amount of bicarbonate/carbonate (100 $\mathrm{mg} / \mathrm{L}$ or more); and

- adding sodium bicarbonate (baking soda) buffer as needed.

Other important water quality parameters that may require monitoring include hardness, salinity, organics, and conductivity. These parameters may increase over time in a system that does not undergo routine water changes, but is only "topped off." In such a situation these parameters may reach levels that are not desirable for maintenance or reproduction of some fish species.

Heavy metals, such as copper, zinc, and lead, are also toxic to fish and may be present in the water source. If they are, methods to remove them should be considered (consult an aquaculture or water filtration specialist), and system levels should be checked regularly. Additionally, heavy metals (such as copper or zinc) may be part of the hardware of the system (though this is highly undesirable) and may begin to leach into the water as the $\mathrm{pH}$ becomes more acidic. Check with an aquaculture specialist for the best construction materials.

Biosecurity Biosecurity is a concept that is simple to understand, but can be difficult for some operations to put into practice. As the term implies, the goal of "biosecurity" is maintaining the "security" of a facility with respect to "biological" organisms, specifically "pathogens" (disease-causing organisms) that can result in infectious disease (parasites, bacteria, viruses, and fungi).
However, because some pathogens are normally found almost everywhere on or in fish or in aquatic systems, these are generally considered less of a concern. By contrast, some pathogens may not be present on a facility or in a specific group of fish, and may cause significant disease. Although many important pathogens for which biosecurity is critical are viruses, such as spring viremia of carp (see IFAS Fact Sheet VM-142, Spring Viremia of Carp), some bacteria, fungi, or parasites can warrant biosecurity measures, more so in closed systems with high stocking densities.

Although biosecurity is an entire topic in and of itself, the essence of biosecurity involves following specific management protocols to prevent specific pathogens from entering a system, or reducing the numbers that do.

Important components of biosecurity include quarantine, sanitation, and disinfection.

Quarantine Quarantine is a standard procedure in public aquaria because pathogens can be introduced with new specimens. These potential disease-causing organisms can result in major disease problems in an established system. Ideally, quarantine protocols should be in place and followed when fish are transferred between facilities, such as when new broodstock are brought into a facility. Adding new fish to an established system without proper quarantine can spread disease from the newly introduced fish to the established stock or from the established stock (which may be healthy, but may be a "carrier" of pathogens) to the newly introduced fish.

Harvesting, shipping, transport, change of diet, and other procedures result in immune system depression. As a result, new fish may be more prone to shedding disease-causing organisms (a lowered immune system results in greater chance for infection and shedding) and infecting other fish or they may be more susceptible to disease from other fish.

Quarantine allows new fish to become acclimated to feeds, water quality, and husbandry protocols, without the added stressors of other fish and pathogens. At the same time, quarantine allows their immune systems time to return to normal so that they 
can combat diseases they may have developed during these changes.

Following quarantine, especially with very valuable fish, one suggested protocol is to place one or more fish from the established stock with one or more fish from the new group for a week or two to determine if there is any lingering disease.

Quarantine protocols should contain the following elements to minimize the potential spread of infectious organisms and to allow the immune systems of new fish to stabilize.

All-in, all-out stocking. Bringing fish in as a group from only one population and keeping these animals together, or all-in, all-out stocking, greatly reduces the potential for exposure to pathogens that are not currently found at some level within that population (i.e., potential cross-contamination from a different group).

Ideally, all-in, all-out quarantine involves an entire system, room or facility. No new fish should be added to a population currently under quarantine.

In some situations (e.g., multi-unit systems) this approach is inefficient or impractical on a system-wide basis. However, at the very least, all-in, all-out stocking should be practiced on a tank-by-tank or vat-by-vat basis. If these tanks can be taken off line until sampling or general prophylactic treatments are performed, chances of introducing pathogens will be reduced.

Isolation or separation. In some ways, isolation or separation resembles and serves the same purpose as all-in, all-out stocking - preventing spread of potential pathogens from one group to another. However, this procedure emphasizes separation or isolation for different populations that must inhabit the same facility where all-in, all-out stocking is not feasible.

All fish in quarantine at a specific time should be isolated or separated from other populations at the facility, preferably in a separate area with dedicated equipment.

Total time spent in quarantine or isolation may vary according to the species of fish; results of sampling for pathogens; commonly found pathogens, their life cycle, and required treatment protocols; potential risks; costs; and space and time limitations. For some retail facilities, this may mean a separate tank system or individual tanks for incoming shipments (especially for species that are typically problematic). Dedicated equipment (nets, siphon hoses, etc.) should be available for each "quarantine" system, or at the very least, an effective disinfectant should be used for equipment shared between systems.

Observation and diet adjustment. Any acclimation protocol will benefit from observation and diet adjustment. Observations of normal and abnormal behaviors can provide information on the status of the fish. Diet adjustment means gradual increase over time in the percentage of the final diet fed until fish are readily taking $100 \%$ of the final diet. A high quality diet should be fed at all times during the transition, taking into account species requirements.

As fish are being acclimated to a new diet daily observations should be made to assess feeding, observe normal behavior, and identify potential disease problems.

Making sure that fish readily eat a manufactured feed makes it easier to treat them with antibiotics because the antibiotics can be added to the feed if necessary. It also provides a stable, balanced base diet to which additional elements can be added as necessary.

Sampling and treatment. When feasible, fish that are under quarantine, or that have been recently brought into a facility, should be sampled or screened to determine the presence of pathogens (i.e., parasites, bacteria, fungi and viruses) prior to their introduction into a system and before any treatment is started. Determining what disease-causing organisms are present allows aquaculturists to be more careful and scientific in their use of treatments and preventative chemicals or antibiotics.

By sampling fish early on for the presence of pathogens or accompanying diseases, scientifically-based treatments can be applied before significant losses occur. At the very least, fish 
brought into a multi-tank or multi-vat system with other fish should be sampled for external parasites.

If necessary, sampling can be performed on live specimens. External samples usually include taking a skin scrape, fin clip and gill clip and examining these tissues under a microscope. If fish cannot be sacrificed, examination of fresh feces may provide information on parasite loads in the gastrointestinal tract.

However, internal examination, which requires the sacrifice of several specimens, is recommended if circumstances allow. Full necropsies (sacrificing fish and carefully examining external and internal tissues with and without the use of a microscope) including microbiology should be performed to rule out the presence of bacterial, viral and fungal diseases, as well as to identify internal parasites. Prior to this approach, however, consultation with a fish health specialist is strongly recommended.

Reduction or elimination of infectious pathogens. Avoid, or at the very least, minimize the introduction of known infectious pathogens. Preventative treatments ("prophylactic" treatments), such as freshwater dips for marine fish or salt water dips for freshwater fish, can be helpful in removing initial loads of external parasites. Use of external parasite treatments, such as formalin or copper may be necessary if sampling demonstrates the presence of parasites susceptible to those treatments. A good clinical history of the fish and information on their origin and possible diseases should be obtained in order to help the aquaculturist and the fish health specialist target their search for possible causes of infectious and non-infectious diseases.

Wholesale and retail operations, especially those working with large numbers of valuable fish, or koi hobbyists with long-term, permanent populations, may want to add one other step. They should consider combining a few members of the "old" or "resident" population with a few members of the "new" population in another system for a week or two at the end of the quarantine period. This approach will help determine if any subclinical infections are present (subclinical means that a very low level of disease is present but not causing obvious symptoms). If this is the case, these diseased fish present in the resident population may cause disease in the new fish or the opposite may occur.

Sanitation Good sanitation practices will help reduce the load of potential pathogens. Such practices include proper system maintenance by removing excess suspended particulates, uneaten food, and dead or dying fish; reducing organics and removing wastes (see UF/IFAS Fact Sheet VM-87 Sanitation Practices for Aquaculture Facilities).

Disinfection Ongoing maintenance should include a disinfection regime (see UF/IFAS Fact Sheet VM-87 Sanitation Practices for Aquaculture Facilities). Elimination of pathogens from nets, siphons and tanks through the use of chemicals (such as chlorine, benzalkonium chloride or iodine-containing compounds), ultraviolet radiation, or ozone will help reduce the potential spread of disease. Foot baths placed at key points leading into and away from quarantine areas or areas with sick fish will also help. Nets should be kept off the floor to avoid contact with pathogens that may be harbored there.

\section{Summary}

Before building a recirculating system, the aquaculturist should have a good understanding of basic preventative medicine and fish diseases that may be exacerbated in these systems. A good understanding of the biology and specific requirements (including nutrition and water quality) of the target fish species are essential. Adhering to the principles of quarantine, sanitation and disinfection will increase the immunocompetence of fish in recirculating systems and reduce their overall parasite loads.

Because the ultimate purpose of a system will determine specific design and management characteristics, this purpose and appropriate system requirements should be thought-out well in advance of purchasing any building or materials.

\section{Recommended Reading}

SRAC Publication No. 479b Columnaris

Disease. http://srac.tamu.edu/479bfs.pdf 
UF/IFAS Circular 57 Streptococcal Infections of Fish. http://edis.ifas.ufl.edu/FA057

UF/IFAS Circular 84 Use of Antibiotics in Ornamental Fish Aquaculture. http://edis.ifas.ufl.edu/FA084

UF/IFAS Circular 121 Fish Health Management Considerations in Recirculating Aquaculture Systems - Part 2: Pathogens. http://edis.ifas.ufl.edu/FA100

UF/IFAS Circular 122 Fish Health Management Considerations in Recirculating Aquaculture Systems - Part 3: General Recommendations and Problem-Solving Approaches. http://edis.ifas.ufl.edu/FA101

UF/IFAS Circular 716 Introduction to Freshwater Fish Parasites. http://edis.ifas.ufl.edu/FA041.

UF/IFAS Circular 919 Stress - Its Role in Fish Disease. http://edis.ifas.ufl.edu/FA005.

UF/IFAS Circular 920 Ichthyophthirius multifiliis (White Spot) Infections in Fish. http://edis.ifas.ufl.edu/FA006.

UF/IFAS Circular 921 Introduction to Fish Health Management. http://edis.ifas.ufl.edu/FA004.

UF/IFAS Fact Sheet FA-14 Aeromonas Infections. http://edis.ifas.ufl.edu/FA042.

UF/IFAS Fact Sheet FA-16 Ammonia. http://edis.ifas.ufl.edu/FA031.

UF/IFAS Fact Sheet FA-28 Mongenean Parasites of Fish. http://edis.ifas.ufl.edu/FA033.

UF/IFAS Fact Sheet FA-29 Introduction to Viral Diseases of Fish. http://edis.ifas.ufl.edu/FA034.

UF/IFAS Fact Sheet FA-31 Vibrio Infections of Fish. http://edis.ifas.ufl.edu/FA036.

UF/IFAS Fact Sheet FA-55 Submission of Fish for Diagnostic Evaluation. http://edis.ifas.ufl.edu/FA055.

UF/IFAS Fact Sheet FA-95 Molds in Fish Feeds and Aflatoxicosis. http://edis.ifas.ufl.edu/FA095.
UF/IFAS Fact Sheet VM-77 Use of Formalin to Control Fish Parasites. http://edis.ifas.ufl.edu/VM061.

UF/IFAS Fact Sheet VM-86 Use of Salt in Aquaculture. http://edis.ifas.ufl.edu/VM007.

UF/IFAS Fact Sheet VM-87 Sanitation Practices for Aquaculture Facilities. http://edis.ifas.ufl.edu/AE081.

UF/IFAS Fact Sheet VM-96 Mycobacteriosis in Fish. http://edis.ifas.ufl.edu/VM055.

UF/IFAS Fact Sheet VM-97 Fungal Diseases of Fish. http://edis.ifas.ufl.edu/VM033.

UF/IFAS Fact Sheet VM-142 Spring Viremia of Carp. http://edis.ifas.ufl.edu/VM106

\section{References and Further Reading}

Bedell G.W. 1971. Eradicating Ceratomyxa shasta from infected water by chlorination and ultraviolet irradiation. Progressive Fish-Culturist 33: 51-54.

Collins M.T., J.B. Gratzek, D.L. Dawe and T.G. Nemetz. 1975. Effects of parasiticides on nitrification. Journal of the Fisheries Research Board of Canada 32: 2033-2037.

Collins M.T., J.B. Gratzek, D.L. Dawe and T.G. Nemetz. 1976. Effects of antibacterial agents on nitrification in an aquatic recirculating system. Journal of the Fisheries Research Board of Canada 33: $215-218$.

Hach Company. 2002. Water Analysis Handbook, Fourth edition. Hach Company, Loveland, CO. $1260 \mathrm{pp}$.

Hoffman G.L. 1974. Disinfection of contaminated water by ultraviolet irradiation with emphasis on whirling disease (Myxosoma cerebralis) and its effect on fish. Transactions of the American Fisheries Society 103: 541-550.

Kasai H., M. Yoshimizu and Y. Ezura. 2002. Disinfection of water for aquaculture. Fisheries Science, Volume 68, Supplement I, pp. 821-824. Blackwell Publishing, Oxford, UK. 
Levine G. and T.L. Meade. 1976. The effects of disease treatment on nitrification in closed system aquaculture. Proceedings from the $7^{\text {th }}$ Annual Meeting of the World Mariculture Society, J.W. Avault Jr. (editor), pp 483-493. World Mariculture Society, Louisiana State University, Baton Rouge, LA.

Miocevic I., J. Smith, L. Owens and R. Speare. 1993. Ultraviolet sterilization of model viruses important to finfish aquaculture in Australia. Australian Veterinary Journal 70: 25-27.

Nagy R. 1964. Application and measurement of ultraviolet irradiation. American Industrial Hygiene Association Journal 25: 274-281.

National Research Council. 1993. Nutrient Requirements of Fish (Committee on Animal Nutrition, Board on Agriculture). National Academy Press, Washington, DC. 114 pp.

Normandeau D.A. 1968. Progress Report, Project F-14-R-3, State of New Hampshire (Mimeo).

Rodriguez J. and T.R. Gregg. 1993.

Considerations for the Use of Ultraviolet in Fish Culture in Techniques for Modern Aquaculture: Proceedings of an Aquaculture Engineering Conference 21-23 June 1993, p 482. American Society of Agricultural Engineers, St. Joseph, MI.

Spotte S. 1979. Fish and Invertebrate Culture: Water Management in Closed Systems, Second edition. John Wiley and Sons Inc., New York, NY. $179 \mathrm{pp}$.

Vlasenko M.I. 1969. Ultraviolet rays as a method for the control of disease of fish eggs and young fishes. Journal of Ichthyology (formerly, Problems of Ichthyology) 9: 697-705.

Yoshimizu M., H. Takisawa and T. Kimura. 1986. UV susceptibility of some fish pathogenic viruses. Fish Pathology 21: 47-52. 